\title{
Where do the physician's responsibilities begin and end?
}

\author{
Barbara \\ Christian Petzold, director \\ Nina Hoss and Ronald Zehrfeld \\ Adopt Films; 2012
}

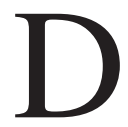

ramatically investigating the personal and political aspects of medical practice, acclaimed German director Christian Petzold's minimalist, absorbing film, Barbara, is a fascinating specimen of contemporary German cinema's confrontations with its recent, divided national history. Set in a northern town in the German Democratic Republic (GDR) in the depths of the Cold War in 1980, Barbara not only depicts daily life under Soviet-style communism, it also examines more specifically the practice of medicine in that political culture, and the ethical issues which arise in such a strictly enforced ideological context. Indeed, Barbara is at once an important film in Germany's postreunification narrative about its Cold War history and an intelligent exploration of the complex role of the physician in society.

The film revolves around Dr. Barbara Wolff who has been dispatched from a prestigious Berlin hospital to a small, shabby one in a town near the Baltic Sea as punishment for having engaged in some previous (and unidentified) forbidden political activity. She is reserved, remote and secretive. Her new colleague and head of the facility, Dr André Reiser, seems to understand and empathizes with her professional and personal struggles. After an initially frosty relationship, they begin to work well together, and André values highly her talent as a diagnostician.

Barbara is also under constant surveillance by state secret police who sit in parked cars outside her apartment, arrive unannounced to search the grubby apartment she's been assigned,

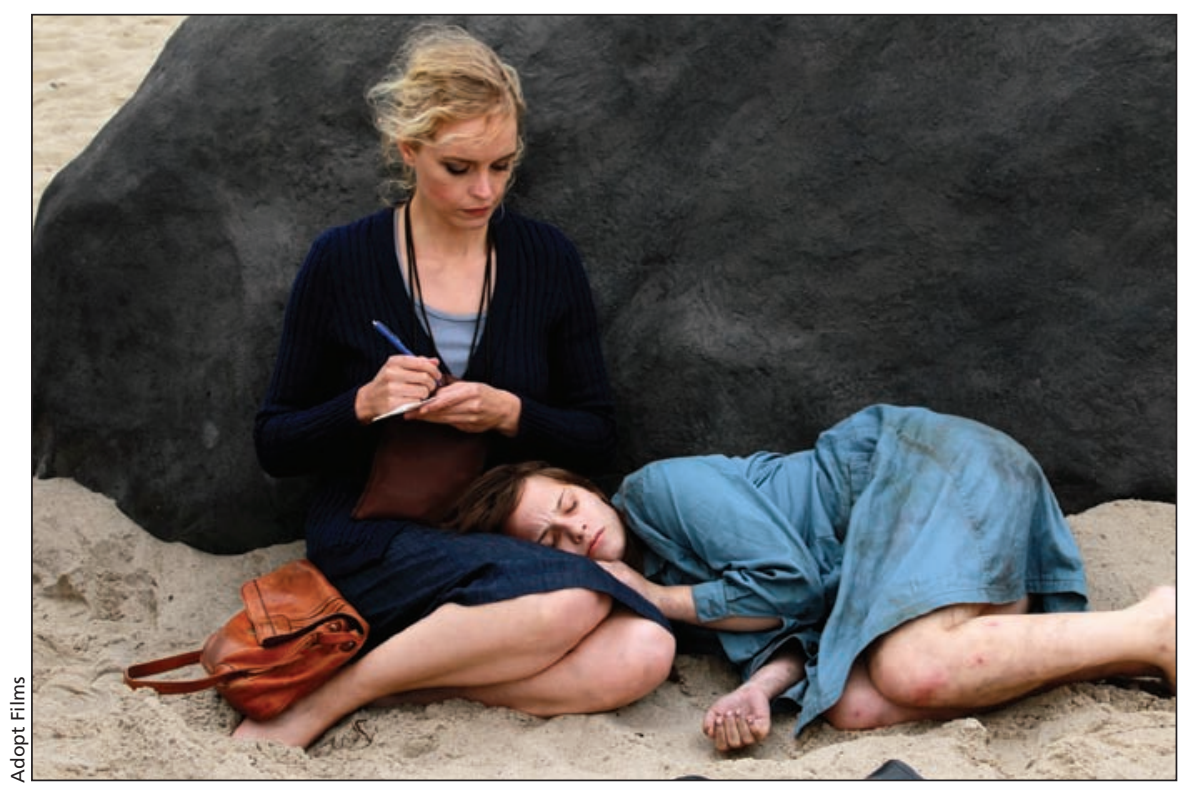

In the film Barbara, Nina Hoss plays an East German doctor circa 1980, who puts the safety of her patient, Stella (Jasna Fritzi Bauer), ahead of her own.

and, nurse in tow, to examine her body cavities. Meanwhile, Barbara meets clandestinely with her lover, who lives in the West and is preparing to have her taken by boat to Denmark.

Despite the mounting tension and her justifiable paranoia, Barbara's furtive escape plans appear to be working, until a young woman named Stella arrives at the hospital. She has been toiling at a forced-labour camp and, as Barbara swiftly diagnoses, has contracted meningitis. After a lumbar puncture is administered as well as several tests, it is discovered that Stella is pregnant. Barbara soon develops an intense concern for her patient, protecting her from the state authorities by delaying her release, and reading Mark Twain's Huckleberry Finn at her bedside. Her interaction with this courageous young woman also puts her defection plans into a new light. Later, she also encounters Mario, a young man who has attempted suicide because of an unrequited love. His idealism and passion further force Barbara to rethink her flight and, more significantly, push her to reconsider her duty as a physician. Can she simply leave patients behind for a new life in West Germany? At what level can she cauterize her emotions and her professional ethics to flee the oppressive GDR?

This is the dramatic and existential crux of Barbara. At what point does the political and ideological situation become completely intolerable and utterly incompatible with the Hippocratic oath? And if it does, what can and what should a physician do? Can he or she simply ignore the conditions of one's practice (in this case, an impoverished health care system with inadequate technologies and facilities), which could be potentially damaging to patients? Can one simply leave patients behind to seek a better life somewhere else? Just where do the physician's responsibilities begin and where do they end?

Wisely, Petzold's film does not offer definitive answers to these complex questions. Instead, Barbara presents a number of perspectives on these ques- 
tions. Primarily through the character of André and his intensifying relationship with Barbara, the film explores the complexities of the physician's role in various societies and across a number of historical periods. For example, André has a print of Rembrandt's famous 1632 painting, "The Anatomy Lesson of Nicolaes Tulp" on the wall of the clinic, which depicts doctors performing an autopsy as they refer to an atlas of anatomy. The ambiguities of perception are represented in this work, André argues, because the painting depicts the perspective of the patient, not the doctors, who are lost in the abstractions of a medical textbook. Later, he gives Barbara a copy of Ivan Turgenev's 1852 book, A Sportsman's Sketches, which contains the story, "The District Doc- tor," a tragic tale of a tangled doctorpatient romance and sexual encounter. These incidents, in addition to Barbara's own struggles with her conscience, contribute to the film's intelligent, occasionally troubling examination of the moral, ethical and medical challenges of reconciling knowledge and action: if I know this, can I do that? Given the relatively recent historical reality of abominable medical practices in the service of Nazi ideology, this fundamental question acquires additional profound and unsettling resonances.

At the dramatic and philosophical centre of Barbara is a telling moment. On the verge of being taken back to the work camp even while pregnant, Stella asks Barbara, "Can you do anything, Doctor?" Barbara's response, charged with the many personal and profession complications involved in her own perilous circumstances, is spare and simple: "I'll try." It is in this exchange that all the vast political, ideological, emotional and psychological complexity of the physician's role in society — any society - is exposed. How does one try? What can one do? Rather than offer prescriptions and answers, the tautly constructed, exquisitely elliptical Barbara offers instead a searching meditation on both the powers and the limitations of physicians working in dangerous times.

Tom McSorley

Executive Director

Canadian Film Institute

Ottawa, Ont.

CMAJ 2013. DOI:10.1503/cmaj.130541

\section{More Humanities online}

\section{Books}

Bursting with Danger and Music, by Jack Coulehan (Plain View Press; 2012). Physician Jack Coulehan's poetry has a powerful capacity to evoke, with breathless wonder, a person's suffering. - Ronna Bloom, Toronto, Ont.

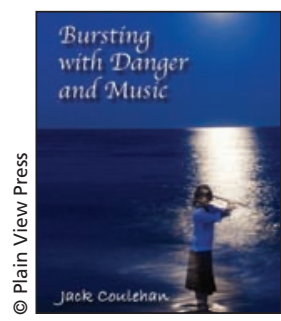

A Healthy Society: How a Focus on Health can Revive Canadian Democracy, by Ryan Meili (Purich Publishing Limited; 2012). This enthusiastic introduction to the literature on the determinants of health by Dr Ryan Meili is both fascinating and a stirring call to action. - Raisa B. Deber, Toronto, Ont.

Humanitarian Negotiations Revealed: The MSF Experience, Clare Magone, Michael Neuman, Fabrice Weismann, editors (C. Hurst and Co. Publishers Ltd.; 2012). As Médecins Sans Frontières (MSF) celebrates its 40th year, 18 contributors reflect on the necessary compromises made with repressive governments that allow MSF to do its humanitarian work. - Gretchen Roedde MD, Temiskaming Shores, Ont.

Referenced Eating, Aileen Burford-Mason with Judy Stoffman (Thomas Allen Publishers; 2012.) Toronto nutritionist Burford-Mason brings her experience as an immunologist, cancer researcher and cell biologist to bear on deciphering the nutrition research about what helps us stay healthy. - Laura Eggertson, Ottawa Ont.

\section{Essay}

Narrative accounts of recovering at home after heart surgery. These 13 poems and photographic images follow the patient's journey through surgery and recovery. - Jennifer L. Lapum, Kathryn Church, Terrence Yau, Perin Ruttonsha, Alison Matthews David, Toronto, Ont.

\section{Encounters}

Virtuoso. A virtuoso performance, whether as a violinist or a resident surgeon, demands far more than the rote practice of technical skills. Above all, it demands the ability to let go intellectually and move with the moment. - Siobhan Deshauer, Toronto, Ont.

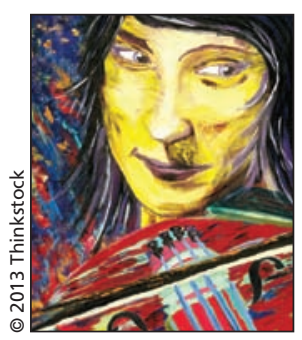

Unprepared. As the medical team delivers a dire diagnosis to a young patient and his family, a medical student grapples with his response - and his unique role. Mikhail Higgins, Philadelphia, Pa.

Oncology sleep. It is in learning to hear a patient's story and in giving ourselves over to their story, that we become a fully fleshed witness to the harsh omnipotence of death. - Tavis Apramian, London, Ont.

To a young doctor. Make every diagnosis a poem. Allan Peterkin, Toronto, Ont.

CMAJ 2013. DOI:10.1503/cmaj.131161 